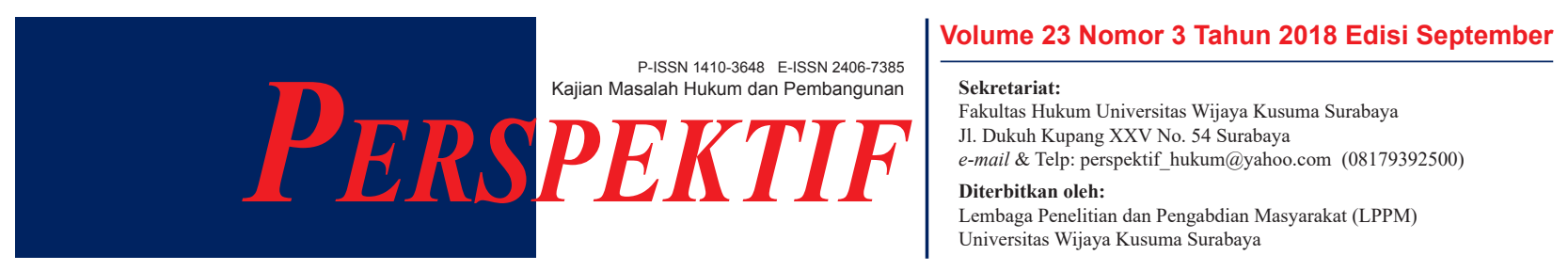

\title{
PERAN SERTA MASYARAKAT \\ DALAM TINDAKAN PENGAMANAN (SAFEGUARD) TERHADAP INDUSTRI DALAM NEGERI
}

\author{
Erwin \\ Magister Kenotariatan, Fakultas Hukum, Universitas Airlangga \\ e-mail: emalondalawfirm@gmail.com \\ Ari Murti Susanto \\ Magister Kenotariatan, Fakultas Hukum, Universitas Airlangga \\ e-mail:armur@yahoo.com \\ Muhammad Fajri \\ Magister Kenotariatan, Fakultas Hukum, Universitas Airlangga \\ e-mail:mfajri85@gmail.com
}

\begin{abstract}
ABSTRAK
Safeguard adalah tindakan yang diambil oleh pemerintah negara pengimpor untuk memulihkan kerugian serius dan/atau mencegah kerugian serius terhadap industri dalam negeri sebagai akibat lonjakan impor barang sejenis atau barang yang secara langsung bersaing. Safeguard sangat perlu untuk dilaksanakan untuk melindungi industri dalam negeri. Sehingga muncul pertanyaan, bagaimana perlindungan hukum bagi industri dalam negeri melalui safeguard dan bagaimana peran pemerintah dan masyarakat dalam menghadapi globalisasi perdagangan melalui safeguard? Metode penelitian ini menggunakan penelitian hukum doktrinal, yaitu menjawab permasalahan menggunakan norma-norma hukum dari norma-norma positif. Hasil penelitian ini menunjukkan bahwa sudah dilaksanakan safeguard untuk melindungi industri dalam negeri melalui beberapa tahapan yaitu penyidikan dan pembuktian, penentuan adanya kerugian atau ancaman kerugian, pengenaan tindakan pengamanan dan jangka waktu. Untuk menghadapi globalisasi perdagangan melalui safeguard dibutuhkan peran masyarakat dan pemerintah. Di mana dibutuhkan kerjasama dan sinergitas dari pemerintah dan masyarakat, khususnya produsen dalam negeri.
\end{abstract}

Kata Kunci: Safeguard; peran serta masyarakat; industri dalam negeri

\section{ABSTRACT}

Safeguard is action taken by Government of importing countris to recover losses and/or prevent the threat of seriuos losses to domestic industries as a result of a surge in imports of similar goods. Safeguard needs to be implemented by importing countries if there is a sharp increase in imports and is proven that there is a serious loss to the domestic industries. So there's question about how is the law protection for domestic industries through safeguard and How is the role of government and society in facing a globalization trade through safeguard? Research method used was doctrinal legal research. doctrinal legal reseach to answer the problem by using the analysis of the legal norm. The result showed that safeguards really need to be implemented in Indonesia for similar imported goods as the efforts of Indonesian government to protect domestic industries if they suffer losses. To implement safeguard on imported, the first step that must be carried out is an investigation, which is followed by the determination of the existence of losses and applying the entry fee for imported goods and quota restrictions. To deal with the globalization of trade, good cooperation is also needed between the Government of Indonesia and all Indonesian people, especially domestic industry producers.

Keywords: Safeguard; the role of the community; domestic industry 


\section{PENDAHULUAN}

Perkembangan perdagangan dan perekonomian di dunia tumbuh semakin pesat. Hal ini juga mempengaruhi perdagangan dan perekonomian di Indonesia. Kemajuan di bidang perdagangan dan perekonomian ditandai dengan berkembangnya kegiatan-kegatan seperti ekspor, impor, investasi, lisensi, perdagangan jasa, hak kekayaan intelektual, perbankan, asuransi, franchise, dan lain-lain.

Perkembangan di bidang perdagangan dan perekonomian di Indonesia dapat kita lihat dengan bergabungnya Indonesia ke dalam organisasi perdagangan dunia atau yang biasa kita kenal dengan WTO (World Trade Organization). Indonesia bergabung dengan WTO melalui ratifikasi Convention Establishing The WTO. Indonesia kemudian mengesahkan dalam Undang-Undang Nomor 7 Tahun 1994 tentang Agreement Establishing The World Trade Organization. Dengan menjadi anggota WTO, Indonesia harus menyesuaikan berbagai peraturan hukum yang ada di Indonesia, sesuai dengan ketentuan yang diatur dalam perjanjian dan kesepakatan dari WTO.

Selain General Agreement on Tariff and Trade (GATT)-WTO, di tingkat regional Indonesia juga turut serta dalam organisasi Asia and Pacific Economic Cooperation (APEC), ASEAN Free Trade Area (AFTA), dan China and ASEAN Free Trade Area (CAFTA). Keikutsertaan Indonesia dalam beberapa organisasi perdagangan internasional baik global maupun regional membawa konsekuensi terhadap hukum nasional khususnya di bidang perdagangan dan perekonomian. Hukum di bidang perdagangan dan perekonoman internasional diperlukan untuk menciptakan rasa keadilan, kepastian, dan kemanfaatan pada kegiatan perdagangan internasional.

Selanjutnya Sunaryati Hartono menyatakan bahwa "kaidah-kaidah hukum baru yang merupakan hukum ekonomi untuk sebagian besarnya tidak lagi berpegang pada asas-asas hukum perdata maupun hukum publik konvensional". ${ }^{1}$ Akan tetapi, dengan timbulnya kebutuhan-kebutuhan baru timbul pula kaidah-kaidah baru dan pranata-pranata baru yang sulit sekali dikategorikan ke dalam sistem hukum konvensional. ${ }^{2}$

Hukum ekonomi pada masa kini tidak hanya mengatur yang ada di dalam negara saja (nasional), tetapi juga dalam bidang hubungan antara negara satu dengan yang lain (internasional). Salah satunya adalah transaksi ekspor dan impor. Untuk mengantisipasi transaksi ekspor dan impor yang semakin maju dan juga semakin banyaknya persoalan hukum dalam bidang ekonomi/perdagangan mengharuskan negaranegara perlu mengatur dengan hukum.

Transaksi ekspor impor adalah transaksi perdagangan internasional (international trade) yang sederhana dan tidak lebih dari membeli dan menjual barang antara pengusaha-pengusaha yang bertempat di negara yang berbeda. ${ }^{3}$ Impor sendiri adalah suatu kegiatan perdagangan dengan cara memasukkan barang dari luar negeri ke dalam negeri. Sedangkan ekspor adalah kegiatan perdagangan dengan cara mengeluarkan barang dari dalam negeri ke luar negeri.

Seiring berkembangnya zaman, barang-barang impor dari luar negeri menjadi lebih diminati masyarakat daripada barang dari dalam negeri. Hal ini dikarenakan barang yang berasal dari luar negeri harganya jauh lebih terjangkau dari barang dalam negeri. Apabila tidak ada tindakan dari Pemerintah, maka dikhawatirkan dapat mengancam industri dalam negeri. Akibat dari bergabungnya Indonesia menjadi negara anggota WTO, maka ada beberapa instrumen kebijakan perdagangan yang diatur oleh WTO diantaranya adalah antidumping, antisubsidi, dan safeguard.

Istilah dumping merupakan istilah yang dipergunakan dalam perdagangan internasional adalah praktek dagang yang dilakukan oleh pengekspor dengan menjual komoditi di pasar internasional dengan harga yang kurang dari nilai wajar atau lebih rendah lagi harga barang di negerinya sendiri atau harga jual kepada negara lain pada umumnya. Praktek ini dinilai tidak adil karena dapat merusak pasaran dan merugikan produsen pesaing di negara

${ }^{1}$ Sunaryati Hartono. (1982). Hukum Ekonomi Pembangunan Indonesia. Bandung: Bina Cipta, h. 20.

2 ibid.

${ }^{3}$ Andrian Sutedi. (2014). Hukum Ekspor Impor. Jakarta: Raih Asa Sukses, h. 39. 
pengimpor. ${ }^{4}$ Sedangkan subsidi adalah bantuan atau insentif yang diberikan pemerintah suatu negara kepada para pelaku ekonomi di negaranya.

Safeguard adalah tindakan pengamanan yang diambil oleh pemerintah untuk memulihkan kerugian serius terhadap industri dalam negeri akibatnya melonjaknya barang impor sejenis. Baik safeguard, antidumping dan antisubsidi ketiganya diatur dalam persetujuan WTO.

Hal yang menarik pada sekarang ini adalah melonjaknya permintaan barang impor sejenis yang masuk ke dalam negeri. Ini dikarenakan barang impor sejenis dari luar negeri harganya lebih terjangkau daripada di dalam negeri. Ini menyebabkan industri dalam negeri dikhawatirkan mengalami kerugian yang serius sehingga perlu dilakukan tindakan pengamanan/safeguard.

Topik mengenai tindakan pengamanan dalam kerangka perdagangan internasional ini pernah di beberapa kali diteliti dan telah dipublikasikan dalam jurnal ilmiah. Perlu kiranya dalam penelitian ini disampaikan literature review atas beberapa artikel ilmiah terdahulu yang telah dipublikasikan dalam 5 (lima) tahun terakhir. Beberapa artikel ilmiah dengan topik safeguards adalah sebagai berikut:

1. Abdurrahman Alfaqiih, Media Hukum, Volume 19 Nomor 1 Tahun 2012, "Harmonisasi Regulasi dan Efektifitas Kelembagaan Safeguard di Indonesia", artikel ini mengkaji mengenai konsistensi ketentuan safeguard di Indonesia dengan ketentuan safeguard WTO dan implementasinya ditinjau dari efektifitas hukum. Hasil dari kajian ini menunjukkan bahwa ketentuan safeguard di Indonesia telah sesuai dengan ketentuan safeguard WTO dalam tataran normatif, namun pada tahap implementasi, kebijakan safeguard ini tidak berjalan efektif; ${ }^{5}$

2. Eva Johan, Jurnal Hukum Internasional, Volume 9 Nomor 4 Juli 2012, "The Protection of Domestic Industry Through Safeguards Instrument GATT/ WTO and its Implementation on Downstream Steel Industri in Indonesia”, artikel tersebut menjelaskan bahwa bagaimana memberikan

${ }^{4}$ A.F. Erawati dan J.S. Badudu. (1996). Kamus Hukum Ekonomi Inggris-Indonesia. Jakarta: ELIPS, h. 37.

5 Abdurrahman Alfaqiih. "Harmonisasi Regulasi dan Efektifitas Kelembagaan Safeguard di Indonesia". Media Hukum. Volume 19 Nomor 1 Tahun 2012, h. 27-43. perlindungan terhadap hasil industri domestik melalui tindakan pengamanan berdasarkan aturan GATT/WTO di Indonesia serta bagaimana penerapan dari ketentuan tindakan pengamanan terhadap hasil industri besi domestik; ${ }^{6}$

3. Agus Setiawan, Jurnal Mercatoria, Volume 10 Nomor 1 Tahun 2017, "Perlindungan Hukum Terhadap Industri Tekstil dan Produk Tekstil Dalam Negeri Melalui Tindakan Pengamanan (Safeguard) di Indonesia Relevansinya Dengan MEA 2015", pengamanan perdagangan (safeguard) terhadap industri tekstil dan produk tekstil dalam negeri dalam perundang-undangan di Indonesia saat ini masih belum efektif memberikan kemajuan yang besar bagi industri tekstil dan produk tekstil dalam negeri. Hal ini terlihat dari masih kurang dapat bersaingnya produk tekstil Indonesia di pasar internasional. Tindakan pengamanan (safeguard) berfungsi untuk melindungi industri dalam negeri dari ancaman kerugian ataupun kerugian atas terjadinya lonjakan impor. Namun, menurut aturan ASEAN Trade in Goods Agreement (ATIGA) tidak diperbolehkan lagi melakukan perlakuan yang berbeda terhadap produk dalam negeri dengan produk asing. Hal inilah yang menimbulkan pertanyaan mengenai peraturan di Indonesia yang mengatur tentang tindakan pengamanan perdagangan (safeguard). ${ }^{7}$

Selain beberapa karya ilmiah yang dipublikasikan dalam jurnal ilmiah juga terdapat beberapa penelitian dalam bentuk skripsi dan tesis dengan topik safeguards, tetapi fokus kajiannya hanya sebatas deskriptif peraturan mengenai safeguards dan bentuk-bentuk perlindungan hukumnya. Dari hasil literature review ketiga artikel tersebut judul yang akan dibahas dalam artikel ini terhindar dari duplikasi terhadap karya ilmiah terdahulu yang telah dipublikasikan.

\footnotetext{
${ }^{6}$ Eva Johan. "The Protection of Domestic Industry Through Safeguards Instrument GATT/WTO and its Implementation on Downstream Steel Industri in Indonesia". Jurnal Hukum Internasional. Volume 9 Nomor 4 Juli 2012, h. 617-636.

${ }^{7}$ Agus Setiawan. "Perlindungan Hukum Terhadap Industri Tekstil dan Produk Tekstil Dalam Negeri Melalui Tindakan Pengamanan (Safeguard) di Indonesia Relevansinya Dengan MEA 2015". Jurnal Mercatoria. Volume 10 Nomor 1 Tahun 2017, h. 18-31.
} 
Dari uraian latar belakang di atas, safeguard di Indonesia perlu dilaksanakan untuk melindungi industri dalam negeri khusunya untuk barang yang sejenis. Oleh karena itu penulisan artikel ini diberi judul "Peran Serta Masyarakat Dalam Tindakan Pengamanan (Safeguard) Terhadap Industri Dalam Negeri”.

\section{PERUMUSAN MASALAH}

Bagaimana bentuk perlindungan hukum terhadap industri dalam negeri melalui tindakan pengamanan atau safeguard?

\section{PEMBAHASAN}

\section{Bentuk Perlindungan Hukum Terhadap Industri Dalam Negeri Melalui Tindakan Pengamanan (Safeguard)}

Perdagangan internasional mengalami perkembangan yang sangat pesat pada saat ini. Transaksi ekspor dan impor semakin mengalami peningkatan yang cukup drastis. Hal ini tentunya berdampak positif dan juga berdampak negatif bagi masyarakat itu sendiri.

Dampak positif ekspor adalah industri dalam negeri semakin berkembang dan dikenal oleh seluruh masyarakat. Dampak positif dari impor adalah masyarakat sebagai konsumen mendapatkan pilihan barang yang beraneka macam untuk barang sejenis, tetapi dampak negatifnya adalah mengancam industri dalam negeri. Oleh karena itu, untuk melindungi industri dalam negeri, pemerintah perlu melakukan tindakan pengamanan atau yang biasa disebut safeguard.

Berdasarkan Article XIX of GATT 1994, Tindakan Pengamanan (Safeguard) adalah tindakan yang diambil oleh pemerintah negara pengimpor untuk memulihkan kerugian serius dan/atau mencegah ancaman kerugian serius terhadap industri dalam negeri sebagai akibat dari lonjakan impor barang sejenis atau barang yang secara langsung bersaing. ${ }^{8}$

Peraturan Menteri Perdagangan Nomor 37/M-Dag/Per/9/2008 menyebutkan bahwa tindakan pengamanan (safeguard) adalah tindakan yang diambil oleh pemerintah untuk memulihkan kerugian dan/atau mencegah ancaman kerugian serius dari industri dalam negeri sebagai akibat dari lonjakan

8 Muhammad Sood. (2011). Hukum Perdagangan Internasional. Jakarta: Raja Grafindo Perkasa, h. 213. impor barang sejenis atau barang yang secara langsung merupakan saingan hasil hasil industri dalam negeri dengan tujuan agar industri dalam negeri yang mengalami kerugian serius dan/atau ancaman kerugian serius tersebut dapat melakukan penyesuaian struktural.

Dari pengertian di atas, bisa disimpulkan bahwa tindakan pengamanan (safeguard) merupakan suatu tindakan yang dilakukan oleh negara pengimpor untuk melindungi industri dalam negeri dari ancaman kerugian yang serius karena lonjakan barang impor yang sejenis. Negara pengimpor boleh memberlakukan tindakan pengamanan (safeguard) apabila memenuhi persyaratan-persyaratan.

Persyaratan-persyaratan untuk negara pengimpor bisa menerapkan safeguard diatur di dalam Article II Agreement on Safeguard, yang berbunyi sebagai berikut: ${ }^{9}$

1. A Member may apply a safeguard measure to a product only if that Member has determined, pursuant to the provisions set out below, that such product is being imported into its territory in such increased quantities, absolute or relative to domestic production, and under such conditions as to cause or threaten to cause serious injury to the domestic industry that produces like or directly competitive products.

2. Safeguard measures shall be applied to a product being imported irrespective of its source.

Dari Article II Agreement on Safeguard, kita bisa melihat bahwa syarat-syarat untuk negara pengimpor bisa menerapkan safeguard adalah: Pertama, apabila produk yang diimpor ke dalam negeri dalam jumlah yang sedemikian rupa, mengancam produk sejenis dalam negeri dan menyebabkan kerugian yang serius. Kedua, tindakan safeguard akan diterapkan oleh negara pengimpor pada produk yang di impor tanpa dilihat sumbernya.

Pengaturan pelaksanaan tindakan pengamanan (safeguard) diatur di dalam beberapa aturan baik dalam internasional maupun nasional diantaranya adalah sebagai berikut:

1. Article XIX GATT sebagaimana disempurnakan dengan Agreement on Safeguard 1994;

2. Undang-Undang Nomor 7 Tahun 1994 tentang Pengesahan Agreement on Establishing The World Trade Organization (WTO);

\footnotetext{
${ }^{9}$ Article II Agreement on Safeguard.
} 
3. Undang-Undang Nomor 17 Tahun 2006 tentang Perubahan UU Nomor 10 Tahun 1995 tentang Kepabeanan;

4. Peraturan Pemerintah Nomor 34 Tahun 2011 tentang Tindakan Anti Dumping, Tindakan Imbalan, dan Tindakan Pengamanan Perdagangan;

5. Peraturan Menteri Perdagangan Republik Indonesia Nomor 37/M-Dag/Per/9/2008 tentang Surat Keterangan Asal (Certifacate of Origin) Terhadap Barang Impor Yang Dikenakan Tindakan Pengamanan (safeguard).

Perlindungan hukum terhadap Industri dalam negeri dari lonjakan barang impor yang sejenis sudah jelas diatur di dalam peraturan-peraturan di atas. Sebelum Pemerintah menerapkan tindakan pengamanan (safeguard) pemerintah harus mentaati terlebih dulu syarat-syarat yang disebutkan pada Article II Agreement on Safeguard. Kemudian ada beberapa tahapan yang harus dilaksanakan pemerintah untuk menerapkan safeguard. Tahapantahapan tersebut adalah penyidikan dan pembuktian, penentuan adanya kerugian atau ancaman kerugian, pengenaan tindakan pengamanan, dan yang terakhir adalah jangka waktu dan peninjauan tindakan pengamanan.

Tahapan pertama adalah penyidikan dan pembuktian. Penyidikan dalam tindakan pengamanan (safeguard) dilakukan oleh Komite Pengamanan Perdagangan Indonesia (KPPI). Pihak-pihak berkepentingan yang mengalami kerugian dapat mengajukan permohonan penyelidikan atas pengamanan kepada KPPI atau atas inisiatif dari KPPI sendiri. Pihak-pihak yang berkepentingan dalam hal ini diatur di dalam Keputusan Menteri Perindustrian dan Perdagangan RI Nomor 85/MPP/ Kep/2/2003 yaitu sebagai berikut: ${ }^{10}$

a. Produsen dalam negeri Indonesia yang menghasilkan barang sejenis barang terselidik dan/atau barang yang secara langsung bersaing;

b. Asosiasi produsen barang sejenis barang terselidik dan atau barang yang secara langsung bersaing;

c. Organisasi buruh yang mewakili kepentingan para pekerja industri dalam negeri.

${ }^{10}$ Keputusan Menteri Perindustrian dan Perdagangan RI Nomor 85/MPP/Kep/2/2003.
Pihak-pihak di atas yang terkena dampak secara langsung dari adanya lonjakan barang-barang impor. KPPI memberikan kesempatan yang sama pada pihak yang berkepentingan untuk menyampaikan buktibuktinya dalam proses pembuktian. Selanjutnya KPPI melakukan verifikasi data yang diperoleh di negara pengekspor atau di negara asal barang terselidik. Dalam waktu paling lama 30 (tiga puluh) hari, berdasarkan penelitian dan bukti-bukti KPPI memberikan keputusan. Keputusan KPPI berupa menolak permohonan dan menerima penyelidikan. KPPI dalam membuat keputusan harus diberitahukan dengan cara tertulis disertai alasan-alasannya.

Tahapan yang kedua adalah penetapan adanya kerugian atau ancaman kerugian. Pengertian kerugian dan ancaman kerugian diatur di dalam Peraturan Pemerintah Nomor 34 Tahun 2011 tentang Tindakan Anti Dumping, Tindakan Imbalan, dan Tindakan Pengamanan Perdagangan.

Kerugian Serius adalah kerugian menyeluruh yang signifikan yang diderita oleh Industri Dalam Negeri. Ancaman Kerugian Serius adalah Kerugian Serius yang jelas akan terjadi dalam waktu dekat pada Industri Dalam Negeri yang penetapannya didasarkan atas fakta-fakta, bukan didasarkan pada tuduhan, dugaan, atau perkiraan, berdasarkan Peraturan Pemerintah Nomor 34 Tahun 2011 tentang Tindakan Anti Dumping, Tindakan Anti Imbalan, dan Tindakan Pengamanan.

Dari pengertian di atas dijelaskan indikator yang dimaksud dengan kerugin serius dan ancaman kerugian serius sehingga untuk menentukan ini kerugian serius dan ancaman kerugian serius tidak boleh hanya dari tuduhan, perkiraan, dan dugaan saja. Oleh karena itu, perlu dilakukan penyelidikan untuk mendapatkan bukti-bukti yang objektif.

Penentuan adanya kerugian yang serius diatur di dalam Pasal 12 Keputusan Presiden Nomor 84 Tahun 2002 di mana penentuan harus didasarkan pada hasil analisis dari seluruh faktor yaitu tingkat dan besarnya lonjakan barang impor yang terselidik baik secara absolut maupun relatif terhadap barang sejenis yang bersaing. Kedua pangsa pasar dalam negeri yang diambil dan yang terakhir perubahan tingkat penjualan, produksi, produktivitas, pemanfaatan kapasitas, keuntungan, kerugian, dan kesempatan kerja. 
Apabila sudah dilakukan penyelidikan dan analisis yang mendalam, maka KPPI akan menemukan fakta-fakta yang akurat sehingga tidak merugikan kedua belah pihak, baik negara pengimpor atau pun negara pengekspor.

Setelah terbukti menyebabkan kerugian yang serius, maka tahapan yang selanjutnya adalah pengenaan tindakan pengamanan. Pengenaan tindakan pengamanan (safeguard) dibagi menjadi 2 (dua) yaitu tindakan pengamanan sementara dan tindakan pengamanan tetap.

Tindakan pengamanan sementara dilakukan apabila terjadi keadaan darurat yang jika ditunda atau tidak dilaksanakan akan menyebabkan terjadinya kerusakan yang sulit diperbaiki. Tindakan pengamanan sementara berupa tarif yang berlaku maksimum 200 (dua ratus) hari. Namun, apabila tidak ditemukan bukti-bukti yang menyatakan bahwa impor barang sejenis tersebut tidak menyebabkan kerugian, maka tarif yang akan dibayarkan harus dikembalikan kepada importir.

Untuk menentukan tindakan pengamanan sementara, Menteri Perindustrian dan Perdagangan bisa mengusulkan rekomendasi tingkatan pengamanan sementara kepada Menteri Keuangan. Berdasarkan usulan tersebut, Menteri Keuangan menetapkan besarnya bea masuk sebagai tindakan pengamanan sementara di mana tindakan pengamanan sementara ini hanya berlaku 200 (dua ratus) hari.

Selanjutnya tindakan pengamanan tetap dapat ditetapkan dalam tiga bentuk meliputi peningkatan bea masuk, penetapan kuota impor, dan kombinasi dari kedua bentuk tersebut. ${ }^{11}$ KPPI dapat menetapkan rekomendasi tindakan pengamanan tetap setelah seluruh proses penyelidikan sudah dilaksanakan. Kemudian dari hasil penyelidikan tersebut menyatakan bahwa berdasarkan fakta-fakta dan bukti yang kuat menyebabkan kerugian serius dan ancaman kerugian serius bagi industri dalam negeri. Tindakan pengamanan tetap diberlakukan selama dianggap perlu untuk dapat memulihkan kerugian serius atau mencegah ancaman kerugian serius pada industri dalam negeri.

Selanjutnya yang terakhir adalah tahapan jangka waktu dan peninjauan tindakan pengamanan. Pada

${ }^{11}$ Christhophorus Barutu. (2007). Ketentuan Antidumping, Subsidi, dan Tindakan Pengamanan (Safeguard) dalam GATT dan WTO. Bandung: Citra Aditya Bakti, h. 119.
Article 7 Agreement on Safeguard yang berbunyi sebaga berikut: "A Member shall apply safeguard measures only for such period of time as may be necessary to prevent or remedy serious injury and to facilitate adjustment. The period shall not exceed four years, unless it is extended under paragraph 2"

Dari article 7 Agreement on Safeguard, dapat diambil kesimpulan bahwa safeguard pada prinsipnya adalah tindakan darurat yang bersifat sementara dengan maksud untuk memulihkan industri dalam negeri. Tindakan tersebut tidak boleh melebihi 4 (empat) tahun, tetapi safeguard dapat diperpanjang asalkan tidak melebihi 8 (delapan) tahun, termasuk jangka waktu pengenaan tindakan safeguard sementara. Syarat dilakukan perpanjangan safeguard adalah untuk mencegah atau memulihkan keadaan akibat kerugian serius yang dialami oleh negara pengimpor. Syarat yang lain adalah adanya bukti bahwa industri dalam negeri sedang dalam proses melakukan penyesuaian.

Dari pembahasan di atas, dapat kita simpulkan bahwa perlindungan hukum terhadap industri dalam negeri sudah dilaksanakan dan diterapkan. Hal ini ditandai dengan bergabungnya Indonesia menjadi negara anggota WTO. Konsekuensinya, kegiatan ekspor dan impor semakin berkembang dengan pesat, tetapi ada yang menjadi kekhawatiran bagi industri dalam negeri adalah masuknya barang-barang impor yang sejenis karena harga barang impor lebih murah, maka untuk melindungi industri dalam negeri dari kerugian dan ancaman kerugian, pemerintah menerapkan tindakan pengamanan atau yang biasa disebut dengan safeguard, dengan didasarkan aturan dari GATT, Agreement On Safeguard, UU Nomor 7 Tahun 1994 tentang Pengesahan Agreement on Establishing The World Trade Organization (WTO), UU Nomor 17 Tahun 2006 tentang Perubahan UU Nomor 10 Tahun 1995 tentang Kepabeanan, PP No 34 Tahun 2011 tentang Tindakan Anti Dumping, Tindakan Anti Imbalan dan Tindakan Pengamanan, dan Peraturan Menteri Perdagangan Republik Indonesia Nomor 37/M-Dag/Per/9/2008 tentang Surat Keterangan Asal (Certifcate of Origin) Terhadap Barang Impor yang Dikenakan Tindakan Pengamanan (Safeguard).

Dalam upaya untuk melaksanakan safeguard ada beberapa tahapan. Tahapan tersebut adalah penyelidikan dan pembuktian, penentuan adanya 
kerugian atau ancaman kerugian, pengenaan tindakan pengamanan, dan jangka waktu dan peninjauan tindakan pengamanan.

\section{Peran Serta Masyarakat dan Pemerintah dalam Menghadapi Globalisasi Perdagangan Internasional Melalui Tindakan Pengamanan}

Peran serta masyarakat dalam perdagangan internasional untuk mengantisipasi diberlakukannya tindakan pengamanan (safeguard) di Indonesia adalah peran serta para pelaku perdagangan yaitu perusahaan pengekspor dan pengimpor. Bagi perusahaan pengimpor diwajibkan untuk patuh dalam menentukan standar barang dan kuota impor yang akan dilakukan. Sedangkan untuk perusahaan pengekspor apabila dikenakan tindakan pengamanan (safeguard) oleh negera tujuan ekpsor segera berkoordinasi dengan direktorat pengamanan perdagangan, atase perdagangan/perwakilan RI di luar negeri, dan instansi terkait lainnya untuk melakukan pembelaan.

Peran serta pemerintah dalam menghadapi globalisasi perdagangan internasional sangatlah besar. Manfaat yang dapat kita rasakan dengan adanya perdagangan internasional adalah perkembangan kegiatan ekspor, baik ekspor migas maupun nonmigas sehingga bisa membantu industri yang berada di dalam negeri. Kita diuntungkan dengan banyaknya potensi sumber daya alam yang dimiliki oleh Indonesia, tetapi kita juga mempunyai kekurangan, yaitu kualitas sumber daya manusianya.

Dengan perkembangan zaman yang semakin pesat, maka mau tidak mau Pemerintah Republik Indonesia harus berperan aktif dalam dunia perdagangan internasional. Hal ini dikarenakan, sistem perekonomian kita tidak dapat dilepaskan dari sistem ekonomi negara-negara lainnya.

Peran Pemerintah Republik Indonesia sangat besar dalam menghadapi globalisasi perdagangan. Peran pemerintah diantaranya adalah menjamin kerjasama dengan negara-negara lain baik bilateral maupun multilateral untuk meningkatkan perekonomian masyarakat. Selain itu, pemerintah juga membuat peraturan dan kebijakan.

Peran pemerintah untuk meningkatkan perekonomian adalah membentuk badanbadan khusunya dalam menghadapi globalisasi perdagangan. Banyaknya kegiatan ekspor dan impor membuat pemerintah harus mempersiapkan badanbadan atau komite. Salah satunya adalah di bidang tindakan pengamanan. Hal ini di latar belakangi dengannya banyak barang impor sejenis yang masuk dalam negeri sehinga mengancam industri dalam negeri.

Pemerintah Republik Indonesia sudah mempersiapkan lembaga-lembaga yang berwenang dalam menangani tindakan pengamanan (safeguard). Lembaga tersebut antara lain Direktorat Pengamanan Perdagangan (DPP) dan Komisi Pengamanan Perdagangan Indonesia (KPPI).

KPPI didirikan pada tahun 2003 melalui SK Menperindag No. 84/MPP/Kep/2/2003 tanggal 17 Februari 2003. SK ini merupakan tindakan lanjut dari Keppres Nomor 84 Tahun 2002 tanggal 16 Desember 2002 tentang Tindakan Pengamanan Industri Dalam Negeri Dari Akibat Lonjakan Impor. Tugas pokok KPPI ialah menyelidiki kemungkinan ditetapkannya safeguard atas industri dalam negeri yang mengalami kerugian serius karena adanya barang impor yang sejenis atau secara langsung bersaing dengan barang yang diproduksi oleh industri dalam negeri yang mengalami lonjakan impor yang besar.

Pengangkatan dan Pemberhentian keanggotaan ditetapkan oleh Menteri Perdagangan. Struktur Keanggotaan KPPI diatur di dalam Permendag Nomor 34 Tahun 2011 yaitu sebagai berikut: a. Ketua dan Wakil Ketua; b. Sekretariat; c. Sub Komite Penyelidikan Sektor Industri dan Pertambangan; d. Sub Komite Penyelidikan Sektor Pertanian, Kehutanan, Kelautan dan Perikanan. ${ }^{12}$

Dalam menjalankan tugas dan fungsinya, anggota KPPI dituntut untuk wajib bersifat netral sehingga tidak boleh dipengaruhi oleh pihak lain. Keberadaan KPPI diharapkan dapat mencegah kerugian serius dan ancaman kerugian serius terhadap industri dalam negeri.

Selain itu, ada juga lembaga Direktorat Pengamanan Perdagangan atau DPP. DPP di bawah Direktorat Jenderal Perdagangan Luar Negeri. DPP mempunyai tugas melaksanakan perumusan dan pelaksanaan kebijakan, penyusunan pedoman, norma, standar, prosedur, dan kriteria serta pemberian bimbingan teknis dan evaluasi pelaksanaan kebijakan di bidang pengamanan perdagangan.

\footnotetext{
12 Tentang Tindakan Anti Dumping, Tindakan Anti Imbalan, dan Tindakan Pengamanan.
} 
DPP juga mempunyai fungsi sebagai berikut:

a. penyiapan perumusan kebijakan pengamanan perdagangan di bidang monitoring dan evaluasi hambatan perdagangan, penanganan hambatan teknis perdagangan, penanganan tuduhan dumping, subsidi, safeguard;

b. penyiapan pelaksanaan kebijakan pengamanan perdagangan di bidang monitoring dan evaluasi hambatan perdagangan, penanganan hambatan teknis perdagangan, penanganan tuduhan dumping, subsidi, safeguard;

c. penyiapan penyusunan pedoman, norma, standar, prosedur, dan kriteria pengamanan perdagangan di bidang monitoring dan evaluasi hambatan perdagangan, penanganan hambatan teknis perdagangan, penanganan tuduhan dumping, subsidi, safeguard;

d. penyiapan pemberian bimbingan teknis dan evaluasi pelaksanaan kebijakan pengamanan perdagangan di bidang monitoring dan evaluasi hambatan perdagangan, penanganan hambatan teknis perdagangan, penanganan tuduhan dumping, subsidi, safeguard;

e. pelaksanaan urusan tata usaha dan rumah tangga Direktorat.

Peran Pemerintah sudah sangat jelas untuk menghadapi globalisasi perdagangan internasional, salah satunya melalui tindakan pengamanan dengan mengoptimalkan tugas dan fungsi KPPI dan DPP. DPP lebih kepada merumuskan menyiapkan menyusun kebijakan. Sedangkan KPPI lebih kepada melaksanakan penyelidikan atas tindakan pengamanan.

Berdasarkan hasil kajian kementerian perdagangan melalui Badan Pengkajian dan Pengembangan Kebijakan Perdagangan, Pusat Kebijakan Perdagangan Luar Negeri pada tahun 2013, peran pemerintah masih dirasa kurang dalam hal proses konsultasi dan pendampingan selama proses investigasi kasus. ${ }^{13}$ Dalam proses konsultasi terkait dengan adanya tindakan pengamanan, maka pemerintah akan selalu membuka proses public hearing terhadap seluruh pihak yag berkepentingan guna mendapat kesempatan untuk klarifikasi dan

13 Badan Pengkajian dan Pengembangan Kebijakan Perdagangan. (2013). Analisis Kebijakan Pengamanan Perdaganngan Indonesia di Negara Tujuan Ekspor. Jakarta: Pusat Kebijakan Perdagangan Luar Negeri, h. 30. memperjuangkan kepentingan eksportir erintah dapat menggunakan konsultasi/negosiasi bilateral dengan negara bersangkutan agar tindakan pengamanan perdagangan terhadap barang ekspor Indonesia tidak dikenakan, atau paling tidak mendapatkan hambatan perdagangan yang minimal. Apabila tidak puas dengan keputusan final yang dibuat negara pengimpor, pemerintah Indonesia dapat membawa kasus antidumping, safeguard, tindakan imbalan ke Dispute Settlement Body di WTO.

Selain itu, diperlukan kerjasama yang baik antara masyarakat baik produsen dan konsumen khusunya dalam negeri untuk dapat bekerjasama memajukan perekonomian sehingga tujuan nasional yang terdapat di Alinea ke-IV Pembukaan UUD RI Tahun 1945 dapat tercapai.

\section{PENUTUP \\ Kesimpulan}

Dari pembahasan di atas, maka dapat kita tarik kesimpulan sebagai berikut: Perlindungan hukum terhadap industri dalam negeri melalui tindakan pengamanan (safeguard) sudah dilaksanakan dengan bergabungnya Indonesia menjadi anggota WTO, dan dibentuk peraturan-peraturan yang mengatur tentang tindakan pengamanan (safeguard). Hal ini dikarenakan makin banyaknya barang impor yang sejenis yang masuk ke dalam negeri sehingga dapat membuat kerugian atau ancaman kerugian bagi industri dalam negeri. Peran serta masyarakat dalam perdagangan internasional untuk mengantisipasi diberlakukannya tindakan pengamanan (safeguards) di Indonesia adalah peran serta para pelaku perdagangan yaitu perusahaan pengekspor dan pengimpor. Bagi perusahaan pengimpor diwajibkan untuk patuh dalam menentukan standar barang dan kuota impor yang akan dilakukan. Sedangkan untuk perusahaan pengekspor apabila dikenakan tindakan pengamanan (safeguards) oleh negara tujuan ekpsor segera berkoordinasi dengan direktorat pengamanan perdagangan, atase perdagangan/perwakilan RI di luar negeri, dan instansi terkait lainnya untuk melakukan pembelaan. Peran Pemerintah sangat penting dalam menghadapi globalisasi perdagangan. Salah satu peran dan upaya Pemerintah RI adalah mengoptimalkan KPPI dan DPP di bawah Kementerian Perdagangan RI. 


\section{Rekomendasi}

Diharapkan ada komitmen antar negara dalam hal pembatasan jumlah barang agar siklus perdagangan tetap berjalan, serta harus ada peran serta dari masyarakat dan komitmen dalam implementasi tindakan pengamanan (safeguards).

\section{DAFTAR PUSTAKA}

\section{Peraturan Perundangan-undangan:}

Undang Nomor 7 Tahun 1994 tentang Agreement Establishing the World Trade Organization.

Undang-Undang Nomor 17 Tahun 2006 tentang Perubahan UU Nomor 10 Tahun 1995 tentang Kepabeanan.

Peraturan Pemerintah Nomor 34 Tahun 2011 tentang Tindakan Anti Dumping, Tindakan Imbalan, dan Tindakan Pengamanan Perdagangan.

Peraturan Menteri Perdagangan Republik Indonesia Nomor 37/M-Dag/Per/9/2008 tentang Surat Keterangan Asal (Certifacate of Origin) Terhadap Barang Impor Yang Dikenakan Tindakan Pengamanan (Safeguard).

Keputusan Menteri Perindustrian dan Perdagangan RI Nomor 85/MPP/Kep/2/2003.

Agreement on Safeguard 1994.

\section{Buku:}

A.F. Erawati dan J.S. Badudu. (1996). Kamus Hukum Ekonomi Inggris-Indonesia. Jakarta: ELIPS.

Andrian Sutedi. (2014). Hukum Ekspor Impor. Jakarta: Raih Asa Sukses.
Badan Pengkajian dan Pengembangan Kebijakan Perdagangan. (2013). Analisis Kebijakan Pengamanan Perdaganngan Indonesia di Negara Tujuan Ekspor. Jakarta: Pusat Kebijakan Perdagangan Luar Negeri.

Christhophorus Barutu. (2007). Ketentuan Antidumping, Subsidi, dan Tindakan Pengamanan (Safeguard) dalam GATT dan WTO. Bandung: Citra Aditya Bakti.

Muhammad Sood. (2011). Hukum Perdagangan Internasional. Jakarta: Raja Grafindo Perkasa.

Peter Mahmud Marzuki. (2007). Penelitian Hukum. Jakarta: Kencana Prenada Media.

Sunaryati Hartono. (1982). Hukum Ekonomi Pembangunan Indonesia. Bandung: Bina Cipta.

\section{Jurnal:}

Abdurrahman Alfaqiih. "Harmonisasi Regulasi dan Efektifitas Kelembagaan Safeguard di Indonesia". Media Hukum. Volume 19 Nomor 1 Tahun 2012, h. 27-43.

Agus Setiawan. "Perlindungan Hukum Terhadap Industri Tekstil dan Produk Tekstil Dalam Negeri Melalui Tindakan Pengamanan (Safeguard) di Indonesia Relevansinya Dengan MEA 2015". Jurnal Mercatoria. Volume 10 Nomor 1 Tahun 2017, h. 18-31.

Eva Johan. "The Protection of Domestic Industry Through Safeguards Instrument GATT/WTO and its Implementation on Downstream Steel Industri in Indonesia". Jurnal Hukum Internasional. Volume 9 Nomor 4 Juli 2012, h. 617-636. 